\title{
EFEKTIVITAS PENDEKATAN TERPADU UNTUK MENINGKATKAN BERPIKIR KRITIS PEMBELAJARAN SEJARAH DI SEKOLAH MENENGAH KEJURUAN (SMK) DI YOGYAKARTA
}

\author{
Emilia Monalita \\ (Dinas Pendidikan Balikpapan) \\ Email: ita_maz2001@yahoo.com,
}

\begin{abstract}
ABSTRAK
Penelitian ini bertujuan untuk menganalisis: (1) efektivitas pendekatan terpadu model connected, nested dan pendekatan parsial dalam meningkatkan berpikir kritis, dan (2) pendekatan mana yang lebih efektif antara model connected, nested, dan pendekatan parsial dalam meningkatkan berpikir kritis. Jenis penelitian ini adalah quasi experiment dengan desain pretes dan postes. Populasi penelitian adalah seluruh peserta didik kelas X pada Sekolah Menengah Kejuruan (SMK) Negeri di Yogyakarta. Sampel dipilih dengan menggunakan teknik simple random sampling. Teknik pengumpulan data dengan cara observasi dan tes evaluasi hasil belajar. Teknik analisis data menggunakan analisis varian (ANOVA), yang dilanjutkan dengan uji scheffe (uji S) dengan taraf signifikansi 0,05. Hasil penelitian menunjukkan bahwa pendekatan terpadu lebih efektif dalam meningkatkan berpikir kritis peserta didik dibandingkan pendekatan parsial. Hal ini dibuktikan dengan adanya perbedaan rata-rata skor hasil belajar peserta didik antara yang menggunakan pendekatan terpadu model connected, nested, dan pendekatan parsial. Dengan demikian urutan pendekatan yang lebih efektif dalam meningkatkan berpikir kritis adalah pendekatan terpadu model nested, model connected, dan pendekatan parsial.
\end{abstract}

Kata kunci: connected, nested, parsial, berpikir kritis.

\section{ABSTRACK}

This study aims to analyze: (1)the effectiveness of the integrated approach of connected and nested models and the partial approach to improve critical thinking, and (2) which approach is more effective between the connected and nested models and the partial approach to improve critical thinking. This was a quasi experimental study employing the pretest and posttest design. The research population comprised all Grade $X$ students of public vocational high schools in Yogyakarta. The sample was selected by using technique simple random sampling. The data were collected through observation and achievement tests. The data were analyzed by means of the analysis of variance (ANOVA), followed by the posthoc Scheffe test ( S-Test) at a significance level of 0.05. The results of the study showed that the integrated approach was more effective to improve the students critical thinking than the partial approach. This was indicated by the difference in the mean score of the learning outcomes between the students taught by the integrated approach of the connected and nested models, and those employing the partial approach. Therefore, the order of the approaches in terms of the effectiveness to improve the critical thinking is consecutively the integrated approach of the nested model, the connected model, and the partial approach.

Key words: connected, nested, partial, critical thinking. 


\section{Pendahuluan}

Pemerintah menetapkan pelajaran sejarah Indonesia disampaikan pada jenjang Sekolah Menengah Kejuruan (SMK) dalam Kurikulum 2013, dengan bentuk pengajaran yang tentunya sangat berbeda dengan pengajaran sejarah sebelumnya. Perbedaan tersebut terlihat dari pendekatan yang dipergunakan dalam menyampaikan materi kepada peserta didik. Sebelum Kurikulum 2013, berkembang pandangan dominan terhadap pelajaran sejarah sebagai pelajaran hafalan yang membosankan karena banyak hal yang harus dihafalkan. Hal ini disebabkan dalam pembelajaran sejarah yang dikejar adalah materinya itu sendiri (Aman, 2011:45).

$$
\text { Pembelajaran sejarah menurut }
$$

Kurikulum 2013 berusaha untuk memandang sebuah peristiwa sejarah secara utuh, sehingga pembelajaran sejarah bukan sekedar kapan dan di mana, tapi mengapa. Peristiwa sejarah dilihat secara terpadu dan terstruktur sesuai dengan proses yang terjadi, sehingga peserta didik harus mengetahui bagaimana kondisi politik, sosial, ekonomi, dan budaya yang melingkupinya. Dengan demikian, guru harus bisa membawa peserta didik berpikir kritis dan masuk kepada zamannya. Oleh karena itu pembelajaran sejarah diharapkan mampu mengembangkan pengetahuan, yang meliputi penerapan konsep, prinsip, atau menganalisis masalah, dan mengevaluasinya, mengembangkan keterampilan, mengolah informasi, menerapkan prosedur hingga mengamalkan nilai-nilai kesejarahan. Kesemua proses di atas perlu dilatihkan secara terus menerus kepada peserta didik lewat proses pembelajaran.

Pelaksanaan Kurikulum 2013, pada pendidikan Sejarah menuntut guru untuk dapat mengajarkan materi-materi dengan cara (Kemendikbud, 2013:22): (1) menggunakan isu-isu aktual untuk dapat mengajak peserta didik dalam mengembangkan kemampuan analisis dan evaluatif; (2) mendorong peserta didik secara aktif (active learning) untuk mencari sumber dan contoh-contoh konkrit dari lingkungan sekitar; (3) merangsang peserta didik untuk berpikir kritis dengan memberikan pertanyaan-pertanyaan disetiap jam pelajaran; (4) mengaitkan konteks lingkungan tempat tinggal peserta didik dengan konteks kesejarahan yang lebih luas.

Tujuan dari pembelajaran sejarah itu sendiri adalah untuk mencetak peserta didik memiliki kemampuan (Kemendikbud, 2013:2): (1) membangun kesadaran tentang pentingnya konsep waktu dan tempat/ruang; (2) mengembangkan kemampuan berpikir historis (historical thinking); menumbuhkan apresiasi dan penghargaan terhadap peninggalan sejarah; menumbuhkan pemahaman terhadap diri sendiri, masyarakat, dan proses terbentuknya bangsa Indonesia melalui sejarah yang panjang dan masih berproses hingga masa kini dan masa yang akan datang; (5) melahirkan empati dan perilaku toleran yang dapat diimplementasikan dalam berbagai bidang kehidupan masyarakat dan bangsa.

Kendala yang dihadapi dalam melaksanakan pembelajaran sejarah adalah: (1) pembelajaran sejarah selama ini hanya mengemukakan faka-fakta yang seringkali mematikan minat peserta didik terhadap sejarah; (2) pembelajaran sejarah belum diajarkan secara holistik, artinya belum dikupas secara multidisipliner; (3) dalam penyampaiannya hanya berusaha mengejar ketercapaian materi tanpa memperhatikan kualitas keterserapan, kedalaman, dan pemahaman materi sehingga kurang mengembangkan keterampilan berpikir kritis peserta didik, dan akibatnya mereka tidak mampu 
menghubungkan antara apa yang mereka pelajari untuk dapat dimanfaatkan dalam kehidupan sehari-hari; (4) pemahaman guru mengenai pendekatan pembelajaran terpadu juga masih terbatas, mereka lebih paham pengajaran sejarah yang membeberkan fakta-fakta, urutan tahun, dan urutan peristiwa atau tokoh-tokoh sejarah.

Melatih berpikir kritis selama pembelajaran sangatlah penting, karena bila peserta didik memiliki kemampuan berpikir kritis, maka baik pula kemampuannya dalam menyusun strategi, taktik, serta berinovasi agar dapat meraih kesuksesan dalam persaingan global. Melalui berpikir kritis, peserta didik diajak berperan secara aktif dan efektif untuk membangun pengetahuannya sendiri. Bila dihubungkan dengan taksonomi Bloom, latihan berpikir kritis terletak pada tingkat analisa-sintesaevaluasi, tidak pada tingkat dibawahnya. yakni mengingat, memahami, dan menerapkan.

Keterampilan berpikir kritis diperlukan sebagai bekal ketika terjun ke dalam masyarakat yang penuh problematika. Hal ini diperkuat dengan pendapat Savage (Savage \& Amstrong, 1996:232), "pupils who leave school with highly developed thinking skill have powerful intellectual tools they can apply to problems they will confront throughout their lives". Ramond Nickerson (Schafersman, 1991:4) menyatakan bahwa orang yang memiliki kemampuan berpikir kritis yang baik akan memiliki karakter dalam hal knowledge, abilities, attitudes, dan habitual ways of behaving.

Murti (2013:15), mengemukakan alasan pentingnya berpikir kritis dipelajari dan dikembangkan, karena: (1) merupakan keterampilan universal dan rasional yang diperlukan pada pekerjaan apapun, untuk memecahkan masalah apapun; (2) diperlukan untuk merespon perubahan yang terjadi dengan cepat dan efektif; (3) dapat meningkatkan keterampilan verbal dan analitik; (4) dapat meningkatkan kreativitas; (5) untuk merefleksi diri (meaningful life).

Dalam dunia SMK, berpikir kritis diperlukan agar lulusan yang dihasilkan dapat terus mengembangkan kemampuan berpikirnya ketika menghadapi perkembangan dan perubahan-perubahan cepat yang terjadi dalam dunia industri. Dengan memiliki kemampuan berpikir kritis maka dapat mengembangkan kreativitas dan dapat terus berinovasi di masyarakat, serta mampu berkompetisi di dalamnya. Komunitas berpikir kritis mendefinisikan berpikir kritis sebagai: "the intellectually disciplined process of actively and skillfully conceptualizing, applying, analyzing, synthesizing, and/or evaluating information gathered from, or generated by observation, experience, reflection, reasoning, or communication as a guide to belief and action" ( Ebosele, 2012:39).

Fisher (2008:10), menyatakan bahwa berpikir kritis adalah intepretasi dan evaluasi yang terampil dan aktif terhadap obervasi dan komunikasi, informasi dan argumentasi. Dengan demikian dapat dijelaskan bahwa berpikir kritis memiliki standart tertentu, karena melibatkan proses aktif dalam tanya jawab dan berpikir tentang pemikiran kita sendiri (intepretasi, merekonstruksi, dan memilih jawaban terbaik dari beberapa alternatif yang ada).

Dengan demikian dapat disimpulkan bahwa berpikir kritis adalah berpikir rasional tentang sesuatu. Kemudian mengumpulkan informasi sebanyak mungkin sebelum mengambil keputusan atau melakukan tindakan. Berpikir kritis dalam belajar adalah pola berpikir secara terbuka yang diperoleh melalui proses pembentukan berpikir yang dapat dipelajari atau diajarkan, dimana di

Emilia Monalita, Efektivitas Pendekatan Terpadu untuk Meningkatkan Berpikir Kritis Pembelajaran Sejarah di SMK Yogyakarta 
dalamnya mempertanyakan bagaimana informasi atau pengetahuan itu diperoleh (bagaimana menerima, menilai, menimbang, dan memutuskan sesuatu masalah).

Santrock (2008:361), menjelaskan bahwa guru dapat membantu peserta didik untuk mengembangkan keterampilan berpikir kritis selama proses pembelajaran di dalam kelas agar menjadi pemikir yang lebih baik. Adapun cara yang dapat dipergunakan dalam adalah sebagai berikut: (a) mengajak peserta didik untuk berpikiran lebih terbuka dengan mengeksplorasi alternatif jawaban; (b) mendorong rasa ingin tahu peserta didik dengan bertanya, merenungkan, menyelidiki, dan meneliti; (c) mendorong peserta didik untuk bersikap cermat, dan memandu mengembangkan serta menyusun pemikiran mereka sendiri; (d) guru menggunakan pertanyaan berbasis pemikiran dalam menyampaikan materi pelajaran, bukan berbasis pelajaran atau fakta semata.

Salah satu upaya pembelajaran sejarah untuk menyesuaikan diri dengan tuntutan Kurikulum 2013 adalah dengan menerapkan pendekatan yang dapat menggali potensi berpikir kritis. Salah satunya adalah dengan pembelajaran terpadu (integrated approach). Pendekatan pembelajaran terpadu pada hakikatnya merupakan suatu pendekatan pembelajaran yang memungkinkan peserta didik baik secara individual maupun kelompok aktif mencari, menggali, dan menemukan konsep serta prinsip secara holistik dan otentik (Pusat kurikulum, 1996:9). Kaitan konseptual yang dipelajari dengan bidang kajian yang relevan akan membentuk skema (konsep), sehingga peserta didik akan memperoleh keutuhan dan kebulatan pengetahuan.

Dalam pendekatan terpadu memberikan kesempatan kepada peserta didik untuk memahami masalah yang ada di lingkungan sekitarnya dengan pandangan secara utuh. Peserta didik diharapkan memiliki kemampuan untuk mengidentifikasi, mengumpulkan, menilai dan menggunakan informasi yang ada di sekitarnya secara bermakna. Dengan demikian pembelajaran sejarah dapat dianalisis dalam konteks yang lebih luas dari berbagai sudut pandang.

Ibn Khaldun (Hasyim, 2012:54), menyatakan bahwa dalam pengkajian sejarah diperlukan sumber yang beragam, pengetahuan yang luas, dan bermacammacam perhitungan yang tepat dan ketekunan. Apabila catatan sejarah hanya didasarkan pada cuplikan-cuplikan peristiwa, tanpa berdasar pada pengetahuan yang jelas tentang prinsip dan fakta sosial, ekonomi, politik, watak peradaban, dan tidak diperbandingkan antara data yang eksplisit dan implisit, maka sejarah akan mudah tergelincir pada kesalahan. Dengan demikian dapat disimpulkan bahwa ilmu sejarah dapat digunakan bersama-sama dengan ilmu sosial lainnya bila konsep yang digunakan relevan dan jelas, sehingga ada hubungan simbiosis mutualisme antara keduanya.

Pada pendekatan pembelajaran terpadu, program pembelajaran disusun dari ilmu sejarah, yang kemudian dikembangkan dalam rumpun ilmu sosial lainnya. Dengan demikian, ilmu-ilmu sosial menjadi ilmu bantu sejarah. Konsepkonsep dari ilmu sosial membantu atau menjadi alat (tools) untuk kajian sejarah yang kritis analitis dan ilmiah. Penggunaan berbagai konsep disiplin ilmu sosial memungkinkan suatu masalah dapat dilihat dari berbagai dimensi sehingga pemahaman dan kedalaman terhadap suatu masalah akan semakin jelas.

Ditinjau dari cara memadukan konsep, keterampilan, topik dan unit tematiknya, Fogarty (1991:xiv) mengemukakan 10 model pendekatan terpadu yaitu: (a) fragmented 
(tergambarkan), (b) connected (terhubung), (c) nested (tersarang), (d) sequence (terurut), (e) shared ( terbagi), (f) webbed (terjaring), (g) threaded (tertali), (h) Integrated (terpadu), (i) immersed (terbenam), dan ( j) Networked (jaringan).

Dalam penelitian ini, yang akan dibahas adalah model connected dan nested. Model connected berusaha menghubungkan satu konsep dengan konsep lain, topik satu dengan topik lain, satu keterampilan dengan keterampilan lain, ide yang satu dengan ide lain tetapi masih dalam lingkup satu bidang studi. Model connected dilandasi oleh anggapan bahwa butir-butir pembelajaran dapat dipayungkan pada induk mata pelajaran tertentu.

Kunci dari model connected menurut Fogaty (1991:14) adalah, "effort to deliberately relate curricula within the discipline rather than assuming that students will understand the connections automatically". Dengan demikian dalam pembelajaran connected, peserta didik diberi kebebasan untuk menceritakan atau mengeksplorasi asumsi-asumsinya dalam mempelajari materi sejarah dan secara otomatis mereka memahami hubungan antar konsep, antar topik, atau antar unitunit pembelajaran.

Contoh cara menghubungkan pembelajaran sejarah dalam model connected adalah sebagai berikut:

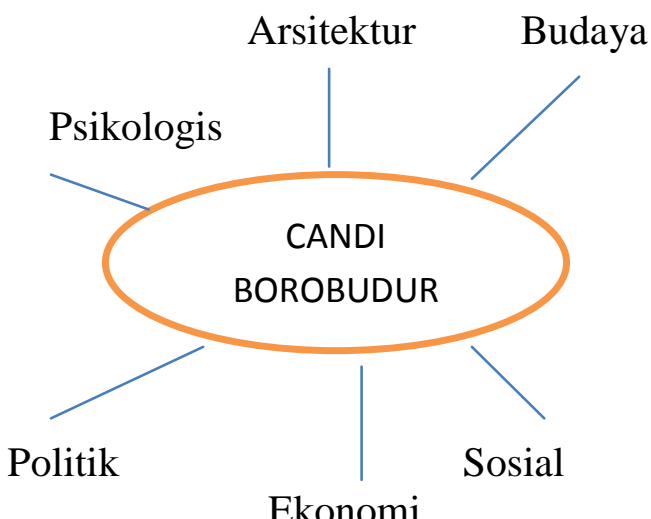

Konsep keterhubungan ditinjau dari :

Politik : legitimasi penguasa

Ekonomi : pembagian kerja

Sosial : masyarakat

Budaya : akulturasi

Arsitektur : local genius

Psikologis : konsep diri, motivasi

Model Nested merupakan model yang memadukan berbagai bentuk keterampilan yaitu keterampilan social (social skill), keterampilan berpikir (thinking skill) dan keterampilan isi (content-specific skill) ketika membahas suatu topik. Keterampilan sosial juga dikembangkan dengan cara belajar secara berkelompok. Model ini merupakan pemaduan berbagai bentuk penguasaan konsep keterampilan melalui sebuah kegiatan pembelajaran. Keterampilan dalam mengembangkan daya imajinasi dan berpikir logis dalam hal ini disikapi sebagai bentuk keterampilan yang tergarap saat peserta didik menggunakan kata-kata dalam kegiatan diskusi. Dengan demikian, model nested berorientasi pada pencapaian multiple skill dan multiple target.

Contoh cara menghubungkan pembelajaran sejarah dalam model nested adalah sebagai berikut:

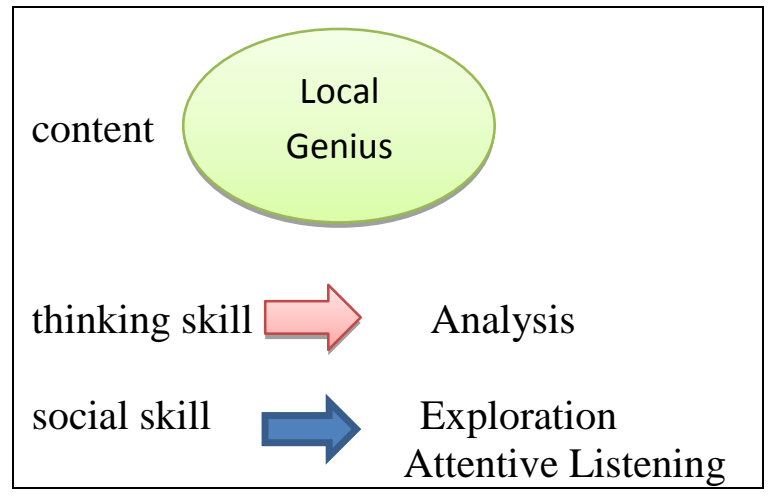

Dari hasil pra survei dan diskusi dengan beberapa guru sejarah di SMK Negeri Yogyakarta, menunjukkan bahwa dalam mengimplementasikan Kurikulum 2013 mereka sudah berusaha untuk mengajarkan sejarah secara holistik, 
namun masih belum memahami bagaimana cara memadukan sejarah dengan ilmu-ilmu sosial yang lain. Dengan kata lain para guru belum mengetahui model-model pembelajaran terpadu dalam penerapannya.

Berdasarkan latar belakang di atas, maka rumusan permasalahan yang dikemukakan adalah: (1) Apakah terdapat perbedaan hasil belajar pelajaran sejarah antara yang menggunakan pendekatan terpadu model connected, model nested, dan pendekatan parsial dalam meningkatkan keterampilan berpikir kritis pada peserta didik di SMK Negeri kota Yogyakarta? (2) Model mana yang lebih efektif antara model connected, model nested dan pendekatan parsial pada pembelajaran sejarah dalam meningkatkan keterampilan berpikir kritis pada siswa SMK Negeri di kota Yogyakarta?

Jawaban dari rumusan permasalahan tersebut dirumuskan dalam bentuk hipotesis sebagai berikut: (1) Terdapat perbedaan hasil belajar antara pembelajaran yang menggunakan pendekatan model connected, model nested, dan pendekatan parsial terhadap pengembangan ketrampilan berpikir kritis pada siswa SMK Negeri di Yogyakarta; (2) Urutan keefektifan pendekatan terpadu dalam meningkatkan keterampilan berpikir kritis pada pembelajaran sejarah adalah: model nested, model connected, dan pendekatan parsial.

\section{Metode Penelitian}

Jenis Penelitian

Penelitian ini mengggunakan jenis penelitian kuantitatif, jenis eksperimen semu (quasi experiment design), dengan bentuk randomized comparation group design. Penelitian dilaksanakan di Sekolah Menengah Kejuruan (SMK) Negeri yang ada di kota Yogyakarta.

Waktu dan Tempat Penelitian
Penelitian dilaksanakan di Sekolah Menengah Kejuruan (SMK) Negeri yang ada di Kota Yogyakarta, dan dilaksanakan mulai pada bulan MaretApril 2014, dengan melakukan pengamatan pada kelas-kelas yang dijadikan sebagai tempat penelitian.

\section{Populasi dan Sampel}

Populasi dalam penelitian ini adalah peserta didik kelas sepuluh (X) pada SMK Negeri yang ada di kota Yogyakarta untuk semua jurusan. Sampel diambil dengan menggunakan teknik simple random sampling. Dari hasil random sampling terhadap SMK Negeri di Yogyakarta, terpilih tiga sekolah sebagai sampel yaitu SMK Negeri 2 (Teknologi), SMK Negeri 4 (Pariwisata) dan SMK Negeri 2 Depok (Teknologi). Hasil akhir random adalah kelas eksperimen ke I, SMK Negeri 2 Yogyakarta pada jurusan Teknik Kendaraan Ringan (TKR) dengan model connected. Kelas eksperimen ke II adalah SMK Negeri 6 Yogyakarta jurusan Usaha Perjalanan Wisata (UPW) dengan model nested. Dengan demikian kelas kontrolnya adalah SMK Negeri 2 Depok jurusan Teknik Komputer dan Jaringan (TKJ) dengan pendekatan parsial.

Variabel Penelitian

Variabel terikat (Y) dalam penelitian ini adalah keterampilan berpikir kritis, yang merupakan hasil belajar dari skor rata-rata pelajaran sejarah. Variabel bebas $(\mathrm{X})$ adalah pendekatan pembelajaran terpadu model connected, model nested, dan pendekatan parsial

Teknik dan Prosedur Penelitian

Teknik dan instrumen pengumpulan data dilakukan dengan: (1) Teknik Observasi, instrumen pengambilan data menggunakan lembar pengamatan, panduan pengamatan, check list observasi, 
dan catatan harian; (2) Teknik Tes, instrumen yang digunakan adalah soal tes obyektif dan essay untuk mengukur keterampilaan berpikir kritis peserta didik.

Validasi instrumen meliputi dua aspek yaitu: (1) Validasi logis, dilakukan oleh expert judgment. Validasi ini meliputi validasi konstruk dan validasi isi; (2) Validasi empiris, yaitu soal tes di uji cobakan di SMK Negeri 2 Depok pada jurusan Teknik Mesin. Uji validitas dilakukan dengan teknik Iteman pada 40 soal pilihan ganda dan 10 soal essay. Soal dianalisis dengan bantuan program SPSS versi 13. Kaidah keputusan yang digunakan adalah :

Jika $r_{\text {hitung }}>r_{\text {tabel }}$ berarti soal test valid

Jika $\mathrm{r}_{\text {hitung }}<\mathrm{r}$ tabel berarti soal tidak valid

Nilai r sebesar 0,341

Validitas soal essay dihitung dengan menggunakan Product Moment. Kriteria yang digunakan adalah bila $r$ hitung $>0,3$ soal dikatakan valid.

Hasil dari pengujian validitas menunjukkan bahwa dari 40 soal pilihan ganda, terdapat 5 soal yang tidak valid. Untuk soal essay seluruh soal yang berjumlah 10 buah dinyatakan valid. Daya beda soal dihitung dengan menggunakan metode Iteman, dan diolah dengan SPSS versi 13. Kriteria pengambilan keputusan yang digunakan (Arikunto, 2012:232) adalah: 0,71-1,00: Sangat baik; 0,41-0,70: Baik; 0,21-0,40: Cukup; 0,00-0,20: Jelek. Berdasarkan hasil perhitungan daya beda, maka dari 40 soal yang diujikan, lima soal dinyatakan tidak valid yaitu nomor 21,22,28, 32, dan 36. Kelima butir soal tadi mendapat daya beda $0,00-0,40$.

Tingkat kesukaran soal dihitung dengan menggunakan metode Iteman, dan diolah dengan SPSS versi 13. Kriteria pengambilan keputusan yang digunakan (Arikunto, 2012:225) adalah: 0,00-0,30:
Sukar; 0,31-0,70: Sedang; 0,71-1,00: Mudah. Hasil perhitungan tingkat kesukaran soal menunjukkan 4 soal dalam kategori sukar, 33 soal sedang, dan 3 soal mudah. Dua soal dalam kategori sedang dan tiga soal dalam kategori mudah ditolak karena tidak valid. Dengan demikian terdapat 35 soal yang dapat digunakan dalam penelitian ( $88 \%$ ). Sisanya $12 \%$ soal dibuang.

Dari butir-butir soal yang valid, dilakukan perhitungan reliabilitasnya. Pengujian reliabilitas dilakukan dengan program SPSS versi 13.00 menggunakan uji statistik Iteman, dan analisisnya menggunakan Cronbach Alpha $(\alpha)$. Suatu variabel dikatakan reliabel jika memberikan nilai Cronbach Alpha sebesar $\geq 0,70$, maka instrumen dianggap handal. Hasilnya diperoleh nilai sebesar 0,933 $\geq$ 0,70 , sehingga instrumen soal memiliki nilai reliabilitas yang tinggi.

Teknik Analisis Data

Teknik analisis data menggunakan anova satu jalur dan uji lanjutan dengan analisis perbandingan ganda (multiple comparation/ MCA) dengan metode Scheffe. Sebelum uji hipotesis dilakukan, terlebih dahulu dilakukan uji persyaratan yang meliputi uji normalitas (menggunakan Kolmogorov-smironov) dan uji homogenitas (menggunakan Lavenne test). Pengolahan data dilakukan dengan bantuan komputer program SPSS versi 13. Hipotesis yang diuji dalam penelitian ini adalah: (1) $\mathrm{Ha}: \mathrm{M}_{1} \neq \mathrm{M}_{2} \neq \mathrm{M}_{3}$; dan (2) $\mathrm{Ha}$ $: \mathrm{M}_{1} \neq \mathrm{M}_{2} ; \mathrm{M}_{1} \neq \mathrm{M}_{3} ; \quad \mathrm{M}_{2} \neq \mathrm{M}_{3}$. Tingkat signifikansi : $\alpha=0,05$. Daerah kritis : $\mathrm{H}_{0}$ ditolak jika p-value (didapat dari sig. $)<\alpha(0,05)$ atau, $\mathrm{H}_{0}$ ditolak jika $\mathrm{F}_{\text {hit }}>\mathrm{F}_{\text {tabel }}$.

\section{Hasil Penelitian dan Pembahasan}

Kelompok data yang didiskripsikan adalah skor hasil belajar pendekatan terpadu model connected, nested, dan 
pembelajaran parsial. Data hasil belajar model connected adalah sebagai berikut:

Tabel 1. Data Hasil Belajar Model Connected

\begin{tabular}{lcc}
\hline \multicolumn{1}{c}{ Hasil } & Pretes & Postes \\
\hline Mean & 26,50 & 75,88 \\
Median & 28,00 & 76,50 \\
Modus & 29 & 68 \\
SD & 4,31 & 8,76 \\
Skor Min & 18 & 61 \\
Skor Maks & 23 & 93 \\
Varian & 10,59 & 81,280 \\
Distribusi & $27,6-29,9$ & $71,8-$ \\
frekuensi & $(34,6 \%)$ & 77,1 \\
& & $(26,9 \%)$ \\
\hline
\end{tabular}

Data hasil belajar model nested adalah sebagai berikut:

Tabel. 2 Data Hasil Belajar Model Nested

\begin{tabular}{lcc}
\hline \multicolumn{1}{c}{$\begin{array}{c}\text { Hasil } \\
\text { Analisis }\end{array}$} & Pretes & Postes \\
\hline Mean & 26,48 & 84,80 \\
Median & 28,00 & 85,00 \\
Modus & 28 & 84 \\
SD & 3,38 & 7,41 \\
Skor Min & 21 & 63 \\
Skor Maks & 33 & 98 \\
Varian & 11,49 & 55,054 \\
Distribusi & $27,3-$ & $86,6-92,4$ \\
frekuensi & 29,3 & $(40,7 \%)$ \\
& $(29,6 \%)$ & \\
\hline
\end{tabular}

Data hasil belajar model parsial adalah sebagai berikut:

Tabel. 3 Data Hasil Belajar Model Parsial

\begin{tabular}{lcc}
\hline \multicolumn{1}{c}{ Hasil } & Pretes & \\
Analisis & & Postes \\
\hline Mean & 25,90 & 58,7 \\
Median & 26,00 & 56,00 \\
Modus & 26,00 & 50,00 \\
SD & 3,25 & 9,01 \\
Skor Min & 17 & 50 \\
SkorMak & 31 & 89
\end{tabular}

\begin{tabular}{lcc} 
s & & \\
Varian & 10,59 & 81,28 \\
Distribus & $24,2-$ & $50-56,5$ \\
i & 26,5 & $(54,8 \%)$ \\
frekuensi & $(38,7 \%)$ & \\
\hline
\end{tabular}

Dari seluruh data di atas, menunjukkan bahwa terdapat perbedaan pada hasil pretes dan postes, dan dapat diketahui bahwa kemampuan awal peserta didik pada seluruh model pembelajaran adalah sama.

Sebelum melakukan uji Anova diberlakukan uji prasyarat yaitu uji normalitas dan homogenitas. Uji Normalitas dilakukan untuk mengetahui apakah data berdistribusi normal atau tidak. Hal ini digunakan untuk menentukan teknik statistik yang digunakan. Uji normalitas menggunakan KolmogorovSmirnov Tes, dengan kaedah pengujian jika sig $\geq 0,05$ maka data berdistribusi normal. Hasil olah data dengan menggunakan SPSS versi 13.00, hasilnya adalah sebagai berikut:

Tabel. 4 Rangkuman Hasil Uji Normalitas

\begin{tabular}{cccc}
\hline & \multicolumn{2}{c}{ Hasil Uji } & \\
\cline { 2 - 3 } $\begin{array}{c}\text { Nendekat } \\
\text { an }\end{array}$ & $\begin{array}{c}\text { Pretes } \\
(\mathrm{sig})\end{array}$ & $\begin{array}{c}\text { Postes } \\
(\mathrm{sig})\end{array}$ & $\begin{array}{c}\text { Kesim } \\
\text { pulan }\end{array}$ \\
\hline $\begin{array}{c}\text { Connecte } \\
d\end{array}$ & 1,282 & 0,433 & Normal \\
Nested & 0,995 & 1,013 & Normal \\
Parsial & 0,944 & 0,983 & Normal \\
\hline
\end{tabular}

Hasil pengujian normalitas di atas, bila dikonfirmasikan pada kaedah pengujian yang telah ditetapkan yaitu sig $\geq$ 0,05, dapat disimpulkan bahwa seluruh data berdistribusi normal. Uji selanjutnya adalah homogenitas untuk mengetahui apakah data berasal dari kelompok populasi yang sama (homogen). Uji homogenitas dilakukan dengan menggunakan Lavene Test, dengan kaedah pengujian: 
1) $\mathrm{f}_{\text {hitung }}<\mathrm{f}$ tabel , maka data dikatakan homogen. Nilai f tabel 3,10 dengan kata lain $\mathrm{f}_{\text {hitung }}<3,10 ; 2$ ) sig $>0,05$, maka data juga dikatakan homogen. Hasil olah statistik dengan SPSS menunjukkan :

Tabel 5. Rangkuman Hasil Uji Homogenitas

\begin{tabular}{ccccc}
\hline & f hit. & df & df & Sig \\
& & 1 & 2 & \\
\hline Pretes & 2,913 & 2 & 81 & 0,060 \\
Postes & 1,105 & 2 & 81 & 0,336 \\
\hline
\end{tabular}

Dengan demikian dapat disimpulkan bahwa data penelitian bersifat homogen, artinya populasi berasal dari kelompok yang sama. Karena data telah memenuhi persyaratan normalitas dan homogenitas, maka uji parametik terpenuhi untuk menguji hipotesis. Pengujian hipotesis I adalah untuk menguji apakah ada perbedaan rata-rata hasil belajar dari ketiga pendekatan $\left(\mathrm{H}_{0}: \mathrm{M}_{1}=\mathrm{M}_{2}=\mathrm{M}_{3}\right)$. Dari hasil pengujian dengan bantuan SPSS, diperoleh hasil bahwa:

Tabel 6. Rata-rata Hasil Evaluasi Pembelajaran

\begin{tabular}{cccc}
\hline $\begin{array}{c}\text { Kegia } \\
\text { tan }\end{array}$ & Connected & $\begin{array}{c}\text { Neste } \\
d\end{array}$ & Parsial \\
\hline Pretes & 26,50 & 26,48 & 25,94 \\
Postes & 75,88 & 84,85 & 58,71 \\
\hline
\end{tabular}

Berdasarkan hasil di atas, dapat disimpulkan bahwa dalam kegiatan pretes rata-rata peserta didik tidak menunjukkan perbedaan hasil yang berbeda jauh. Hal ini menguatkan asumsi bahwa pada saat penelitian dilakukan subyek penelitian dalam kategori memiliki kemampuan yang sama pada kelas connected, nested, dan parsial. Berdasarkan hasil postes, menunjukkan adanya perbedaan rata-rata dari ketiga pendekatan. Bila digambarkan dalam bentuk grafik adalah sebagai berikut:

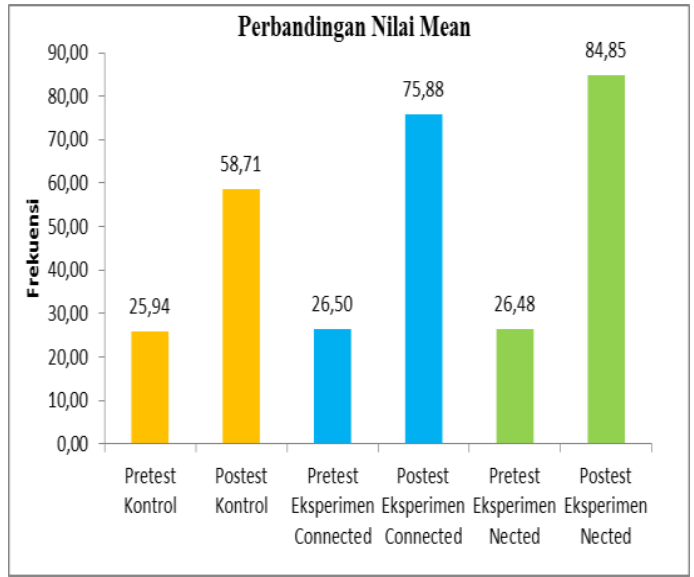

Gambar 1. Perbandingan Nilai Rata-rata Evaluasi Belajar

Hasil di atas diperkuat pula dengan hasil uji anova satu jalur sebagai berikut:

Tabel. 7 Rangkuman Hasil Anova Satu Jalur

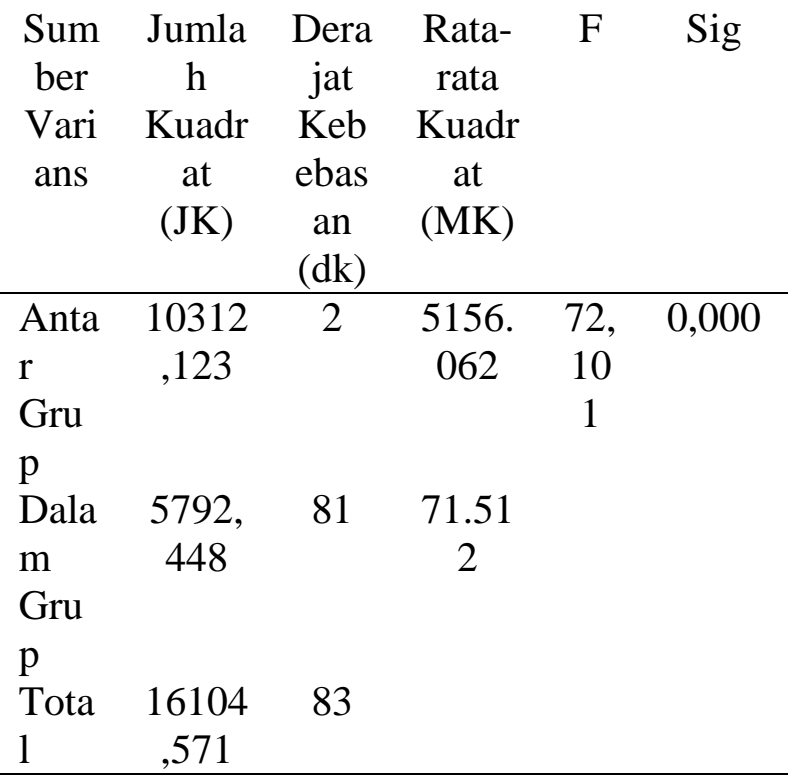

Dari hasil anova di atas diperoleh nilai $\mathrm{F}$ sebesar 72,101 dan p sebesar 0,000. Karena nilai p $0,000<0,05$ maka dengan demikian $\mathrm{H}_{0}$ ditolak, sehingga $\mathrm{Ha}$ diterima. Hal ini berarti ada perbedaan yang signifikan antara pendekatan model connected, model nested, dan pendekatan parsial dalam mengembangkan 
keterampilan berpikir kritis $(\mathrm{M} 1 \neq \mathrm{M} 2 \neq$ M3).

Selanjutnya dilakukan uji hipotesis kedua yaitu $\mathrm{H}_{0}: \mathrm{M}_{1}=\mathrm{M}_{2} ; \mathrm{H}_{0}: \mathrm{M}_{1}=\mathrm{M}_{3} ; \mathrm{H}_{0}$ : $\mathrm{M}_{2}=\mathrm{M}_{3}$, dengan menggunakan uji lanjutan teknik Scheffe (Uji S) untuk membandingkan antara model connected dengan nested, connected dengan parsial, dan nested dengan parsial. Berdasarkan hasil olah data dengan menggunakan SPSS versi 13 terhadap kegiatan postes, hasilnya dapat dilihat sebagai berikut:

Tabel. 8 Rangkuman Hasil Uji Scheffe

\begin{tabular}{cccccc}
\hline $\begin{array}{c}\text { Model yang } \\
\text { dibandingka } \\
\mathrm{n}\end{array}$ & $\begin{array}{c}\text { Mea } \\
\mathrm{n} \\
\text { diffe } \\
\text { rent }\end{array}$ & $\mathrm{p}$ & $\mathrm{F}$ & $\begin{array}{c}\text { Kesim } \\
\text { pulan }\end{array}$ \\
\hline Conn & Nes & 5,45 & 0,0 & 16,1 & Signifi \\
ected & ted & & 01 & 95 & kan \\
Conn & Par & 17,1 & 0,0 & 52,6 & Signifi \\
ected & sial & 7 & 00 & 05 & kan \\
Neste & Par & 22,6 & 0,0 & 142, & Signifi \\
$d$ & sial & 2 & 00 & 719 & kan \\
\hline
\end{tabular}

Hasil dari analisis scheffe di atas menunjukkan bahwa $\mathrm{H}_{0}$ ditolak karena semua model pendekatan yang dibandingkan memperoleh hasil $\mathrm{p}<0,05$, dan $\mathrm{f}_{\text {hitung }}>\mathrm{f}_{\text {tabel }}=4,01$. Hal ini berarti ada perbedaan yang signifikan antara pendekatan model connected, model nested, dan pendekatan parsial dalam mengembangkan keterampilan berpikir kritis.

Perbedaan antara pendekatan model connected dan model nested memperoleh mean different 5,45 dengan $\mathrm{p}$ $=0,001$. Karena p sebesar 0,001 <0,05 dapat disimpulkan terdapat perbedaan yang signifikan antara pendekatan connected dan nested. Nilai $\mathrm{F}_{\text {hitung }}$ memenuhi kaidah yang ditentukan yaitu $\mathrm{F}_{\text {hitung }}>\mathrm{F}_{\text {tabel }}$, karena $F_{\text {hitung }} 16,195>F_{\text {tabel }}=4,01$.
Dengan kata lain $\mathrm{H}_{0}$ yang menyatakan tidak ada perbedaan antara model connected dan model nested ditolak, dan sebaliknya $\mathrm{Ha}$ yang menyatakan ada perbedaan antara model connected dan nested diterima. Rata-rata model connected 75,88 dan model nested 81,33 menunjukkan adanya perbedaan yang signifikan, dimana rata-rata model nested lebih tinggi dibandingkan connected $(81,33$ $>75,88)$. Dengan demikian model nested lebih efektif dalam mengembangkan keterampilan berpikir kritis dibandingkan model connected.

Perbedaan antara pendekatan connected dan parsial memperoleh mean different 17,17 dengan $\mathrm{p}=0,000$. Karena $\mathrm{p}$ sebesar $0.000<0,05$ dapat disimpulkan terdapat perbedaan yang signifikan antara pendekatan terpadu model connected dan pendekatan parsial. Nilai $F_{\text {hitung }}$ memenuhi kaidah yang ditentukan yaitu $\mathrm{F}_{\text {hitung }}>\mathrm{F}_{\text {tabel }}$, karena $\mathrm{F}_{\text {hitung }}$ 52,605 > $\mathrm{F}_{\text {tabel }}=4,01$. Dengan kata lain $\mathrm{H}_{0}$ yang menyatakan tidak ada perbedaan antara model connected dan pendekatan parsial ditolak, dan sebaliknya $\mathrm{Ha}$ yang menyatakan ada perbedaan antara model connected dan pendekatan parsial diterima. Rata-rata model connected 75,88 dan pendekatan parsial 58,71 menunjukkan adanya perbedaan yang signifikan dimana rata-rata model connected lebih tinggi dibandingkan pendekatan parsial $(75,88>58,71)$. Dengan demikian model connected lebih efektif dalam mengembangkan keterampilan berpikir kritis dibandingkan pendekatan parsial.

Perbedaan antara pendekatan model nested dan pendekatan parsial memperoleh mean different 22,62 dan $\mathrm{p}=$ 0,000 . Karena p sebesar $0.000<0,05$ dapat disimpulkan terdapat perbedaan yang signifikan antara pendekatan terpadu model nested dan pendekatan parsial. Nilai $F_{\text {hitung }}$ memenuhi kaidah yang 
ditentukan yaitu $\mathrm{F}_{\text {hitung }}>\mathrm{F}_{\text {tabel }}$, karena $F_{\text {hitung }} 142,719>F_{\text {tabel }}=4,01$. Dengan kata lain $\mathrm{H}_{0}$ yang menyatakan tidak ada perbedaan antara model nested dan pendekatan parsial ditolak, dan sebaliknya Ha yang menyatakan ada perbedaan antara model nested dan pendekatan parsial diterima. Rata-rata model nested 81,33 dan pendekatan parsial 58,71 menunjukkan adanya perbedaan yang signifikan, dimana rata-rata model nested lebih tinggi dibandingkan model parsial $(81,33>58,71)$. Dengan demikian model nested lebih efektif dalam mengembangkan keterampilan berpikir kritis dibandingkan pendekatan parsial.

Berdasarkan hasil perhitungan SPSS di atas, maka urutan model pendekatan yang lebih efektif dalam mengembangkan keterampilan berpikir kritis adalah pendekatan terpadu model nested, model connected, dan pendekatan parsial.

Dalam proses pembentukan keterampilan berpikir kritis peserta didik. yang diamati adalah kemampuan menganalisis, mensintesis, dan mengevaluasi terhadap sebuah konsep, masalah, atau fakta. Kriteria yang dibelakukan dalam pengamatan proses berpikir kritis adalah: 2,51-3,30: sangat kritis; 1,71-2,50: kritis; 0,91-1,70: cukup kritis; 0,11-0,90: kurang kritis. Berdasarkan hasil pengamatan dan skor yang diperoleh, maka proses pembentukan keterampilan berpikir kritis pada pembelajaran model connected telah mencapai kategori mampu berpikir secara kritis. Hal ini ditunjukkan dengan hasil seperti di bawah ini:

Tabel. 9 Hasil Observasi Pendekatan Connected

\begin{tabular}{cccc}
\hline $\begin{array}{c}\text { Pertem } \\
\text { uan ke }\end{array}$ & $\begin{array}{c}\text { Kategor } \\
\text { i }\end{array}$ & $\begin{array}{c}\text { Frekuens } \\
\text { i }\end{array}$ & Persentse \\
\hline 1 & Kritis & 4 & $66,6 \%$ \\
2 & Kritis & 5 & $83,33 \%$
\end{tabular}

\begin{tabular}{lllc}
3 & Kritis & 5 & $66,6 \%$ \\
4 & Kritis & 3 & $50 \%$ \\
\hline
\end{tabular}

Demikian pula dalam pembelajaran model nested, peserta didik mampu untuk berpikir kritis. Hal ini ditunjukkan dalam tabel di bawah ini:

Tabel 10. Hasil Observasi Pendekatan Nested

\begin{tabular}{cccc}
\hline $\begin{array}{c}\text { Pertem } \\
\text { uan ke }\end{array}$ & $\begin{array}{c}\text { Kategor } \\
\text { i }\end{array}$ & $\begin{array}{c}\text { Frekuens } \\
\text { i }\end{array}$ & Persentse \\
\hline 1 & Cukup & 5 & $83,3 \%$ \\
& Kritis & & \\
2 & Kritis & 3 & $50 \%$ \\
3 & Kritis & 5 & $83,3 \%$ \\
4 & Kritis & 4 & $66,7 \%$ \\
\hline
\end{tabular}

Hasil eksperimen memperkuat pandangan teoritis yang menjelaskan bahwa pendekatan pembelajaran terpadu lebih efektif dibandingkan pembelajaran parsial atau terpisah. Hal ini disebabkan dalam pembelajaran terpadu menekankan pada proses keaktifan dan keterlibatan siswa selama kegiatan belajar mengajar sehingga menjadikan belajar lebih bermakna, dan hasilnya lebih bertahan lama bila dibandingkan dengaan pembelajaran yang menekankan pada aspek hafalan.

Pembelajaran terpadu menekankan keaktifan peserta didik dalam pembelajaran baik secara fisik, mental, intelektual, maupun emosional guna tercapainya hasil belajar yang optimal dengan mempertimbangkan hasrat, minat, dan kemampuan siswa sehingga mereka termotivasi untuk terus menerus belajar. Dengan pembelajaran ini peserta didik dapat berfikir lebih kreatif, karena guru hanya sebagai fasilitator. Pendekatan terpadu intinya memadukan dua unsur atau lebih dalam suatu kegiatan pembelajaran. Unsur yang dipadukan dapat berupa konsep dengan proses, 
konsep dari satu mata pelajaran dengan konsep mata pelajaran lain, atau dapat juga berupa penggabungan fakta yang satu dengan fakta yang lain.

Kelebihan pendekatan terpadu dalam pembelajaran sejarah karena diajarkan secara holistik, dan fenomenafenomena sejarah dikaji dalam berbagai sudut pandang. Contohnya dalam tema Sultan Iskandar Muda tidak hanya dibahas dari kapan berdirinya kerajaan, siapa pendirinya, raja terkenalnya, bagaimana silsilah kerajaan, atau tahun berapa kerajaannya berdiri, namun dikaji secara mendalam lewat analisis dari aspek sosialnya, mengapa ekonominya dititik beratkan pada aspek maritim, perkembangan budayanya. Analisis tersebut kemudian direfleksikan pada masa sekarang dalam hal peninggalan materiil dan non materiil yang masih dilaksanakan sampai sekarang, teladan-teladan apa yang bisa dicontoh dari perilaku Sultan Iskandar Muda.

Dalam kegiatan pembelajaran terpadu, peserta didik diarahkan untuk mengajukan pertanyaan kritis tentang "mengapa" atau "bagaimana" sebuah fenomena sejarah dapat terjadi. Contohnya adalah dalam proses islamisasi di Indonesia, peserta didik menggali informasi mengapa Kerajaan Malaka yang letaknya di luar wilayah Indonesia justru mempunyai peranan penting dalam proses islamisasi. Mereka dilatih untuk menggabungkan fakta-fakta sejarah yang ada untuk kemudian diambil sebuah kesimpulan dalam memecahkan masalahmasalah peristiwa sejarah.

Dengan demikian peserta didik dalam pendekatan terpadu diajak untuk langsung mengalami proses pembelajaran mulai dari menemukan, memproses, dan menarik kesimpulan dari fakta-fakta dan konsep-konsep sejarah. Mereka diajak untuk membuka wawasan bahwa sebuah permasalahan tidak dapat dikaji hanya dari satu sudut pandang saja, melainkan harus mempertimbang kan aspek-aspek lain yang ada disekitarnya.

Kelebihan pendekatan terpadu terbukti pula dari hasil eksperimen yang menunjukkan adanya perbedaan rata-rata yang signifikan pada setiap kelompok eksperimen dan kelas kontrol, dimana rata-rata hasil evaluasi kelas eksperimen lebih tinggi bila dibandingkan dengan kelas kotrol.

Dengan demikian pendekatan terpadu dapat dijadikan sebagai salah satu model pembelajaran yang dapat meningkatkan kemampuan berpikir kritis peserta didik. Hal ini disebabkan karena dalam pembelajaran terpadu peserta didik diberi kesempatan untuk secara bebas mengeksplorasi asumsi-asumsinya dalam mempelajari sejarah dengan tetap berpijak pada hubungan antar konsep, hubungan kausalitas, dan hubungan antar fakta-fakta sejarah. Oleh karena itu tidaklah berlebihan bila pembelajaran terpadu dapat diimplementasikankan untuk mengembang kan keterampilan berpikir kritis dalam pembelajaran sejarah, karena unsur-unsur yang membentuk pendekatan terpadu dapat mendorong pembentukan berpikir kritis tersebut.

Keefektifan model nested dibanding kan model connected dan pendekatan parsial disebabkan dalam implementasinya lebih banyak memberikan ruang kepada peserta didik untuk mengembangkan pembelajaran sejarah lewat kegiatan diskusi dan menggali permasalah-permasalahan dalam peristiwa sejarah dengan cara mengembangkan pertanyaan dan jawaban kritis. Selama proses eksperimen, kegiatan belajar peserta didik tidak pernah meninggalkan kegiatan diskusi kelompok dan mengembangkan pertanyaanpertanyaan kritis yang muncul dari pikiran peserta didik tanpa tergantung pada buku paket. Setiap kegiatan pembelajaran 
terintegrasi dengan keterampilan sosial yang diukur lewat target pembelajaran melalui tugas-tugas yang dirancang untuk peserta didik, sehingga secara individual mereka dapat mengembangkan dirinya sendiri.

Keefektifan pendekatan connected dibandingkan pendekatan parsial terletak pada bagaimana pendekatan ini lebih kompleks dalam melihat sebuah faktafakta sejarah dari berbagai sudut pandang. Dalam pembelajaran parsial sebuah peristiwa sejarah lebih banyak dikaji secara faktual saja, tidak mengedepankan aspek analisis, sintesis, dan evaluasi. Selain itu dalam pembelajaran parsial peran peserta didik dalam proses pembelajaran masih kurang dieksplorasi. Dengan demikian secara keseluruhan urutan pendekatan yang lebih efektif adalah model nested, connected, dan parsial.

Dalam observasi pembelajaran yang dilakukan dapat disimpulkan bahwa antara pendekatan connected dan nested sama-sama berada dalam kriteria mampu berpikir kritis selama eksperimen berlangsung. Hal ini menunjukkan bahwa peserta didik pada jenjang SMK mampu dan siap dalam mengembangkan keterampilan berpikir kritis, sehingga tidak perlu ragu untuk menjalankan pembelajaran yang berorientasi pada peserta didik. Hal ini didukung pula oleh fase perkembangan kognitif berdasar teori Piaget, yang menyatakan bahwa seorang anak mengikuti empat tahapan perkembangan yaitu sensorimotor, praoperasional, operasional konkrit, dan operasional formal. Peserta didik di SMK berada dalam tahap operasional formal yang memungkinkan mereka untuk mengembangkan keterampilan berpikir kritis. Dengan demikian guru hendaknya tidak lagi menganggap bahwa pengembangan keterampilan berpikir kritis adalah semata-mata hanya menjadi efek pengiring saja dalam proses pembelajaran, namun benar-benar digali dan dieksploitasi dalam diri peserta didik.

Bila ditinjau secara statistik, antara model connected dan nested, terdapat perbedaan rata-rata hasil belajar sebesar 5,45 dengan nilai sig 0,001 . Karena $\mathrm{p}<$ 0,05 maka secara signifikan terdapat perbedaan antara pembelajaran model connected dan nested. Dengan demikian kaedah pengujian yang berlaku adalah pendekatan dengan model nested lebih efektif dalam mengembangkan keterampilan berpikir kritis dibandingkan model connected. Hal ini ditunjukkan oleh skor rata-rata model nested $=84,85>$ skor rata-rata model connected $=75,88$.

Keefektifan model nested juga terlihat ketika dibandingkan dengan pembelajaran parsial, dengan perbedaan rata-rata hasil evaluasi sebesar 22,62 dan nilai sig 0,000 . Dengan $\mathrm{p}=0,000<0,05$ dapat disimpulkan bahwa model nested memiliki perbedaan yang signifikan, dan lebih efektif dibandingkan pendekatan parsial. Hal ini ditunjukkan oleh skor ratarata model nested $=84,85>$ skor rata-rata pendekatan parsial $=58,71$.

Pendekatan terpadu model connected dengan pendekatan parsial juga menunjukkan adanya perbedaan rata-rata sebesar 17,17 dengan nilai sig $=0,000$. Dengan $\mathrm{p}=0,000<0,05$ maka disimpulkan bahwa model connected memiliki perbedaan yang signifikan dibandingkan dengan pendekatan parsial, dan yang lebih efektif model connected. Hal ini ditunjukkan oleh skor rata-rata model connected $=75,88>$ skor rata-ratarata pendekatan parsial $=58,71$. Dengan demikian secara keseluruhan urutan pendekatan yang lebih efektif adalah pendekatan terpadu model nested, model connected, dan pendekatan parsial.

Dalam observasi pembelajaran yang dilakukan, dapat disimpulkan bahwa peserta didik dalam pendekatan terpadu model connected dan model nested sama-

Emilia Monalita, Efektivitas Pendekatan Terpadu untuk Meningkatkan Berpikir Kritis Pembelajaran Sejarah di SMK Yogyakarta 
sama berada dalam kriteria mampu mengembangkan berpikir kritis. Hal ini menunjukkan bahwa peserta didik pada jenjang SMK mampu dan siap dalam mengembangkan keterampilan berpikir kritis, sehingga tidak perlu ragu untuk menjalankan pembelajaran yang berorientasi pada peserta didik. Hal ini didukung pula oleh fase perkembangan kognitif mereka yang memungkinkan untuk mengembangkan keterampilan berpikir kritis.

Dalam proses pembentukan berpikir kritis, peserta didik mampu untuk merumuskan pertanyan kritis dalam pembelajaran, mendiskripsikan jawaban berdasarkan pemikiran sendiri, mengidentifikasi alternatif-alternatif jawaban hingga sampai pada penarikan kesimpulan selama proses diskusi. Dengan demikian peserta didik mendapatkan pengalaman belajar yang lengkap dari aspek keterampilan berpikir dan keterampilan sosialnya.

\section{Penutup}

Simpulan

Berdasarkan hasil penelitian dan pengujian hipotesis yang telah dilakukan, dapat disimpulkan sebagai berikut: (1) Pembelajaran terpadu terbukti secara signifikan dapat mengembangkan keterampilan berpikir kritis. Pernyataan ini dapat dibuktikan lewat pengujian hipotesis yang telah dilaksanakan bahwa ada perbedaan hasil belajar pada pembelajaran sejarah antara peserta didik yang belajar dengan pendekatan terpadu model connected, model nested, dan pendekatan parsial. Unsur-unsur yang terdapat dalam pembelajaran terpadu sejalan dengan usaha-usaha untuk mengembangkan keterampilan berpikir kritis; (2) Dari hasil pengujian hipotesis yang menerima hipotesis alternatif $(\mathrm{Ha})$, dan adanya pengujian lanjutan (uji Scaffe) dapat disimpulkan bahwa pendekatan terpadu model nested lebih efektif dibandingkan model connected dalam meningkatkan keterampilan berpikir kritis peserta didik. Perbedaan skor rata-rata ditunjukkan dengan nilai sebesar 5,45. Model connected lebih efektif dibandingkan pendekatan parsial dengan perbedaan skor rata-rata sebesar 17,17. Model nested lebih efektif dalam meningkatkan keterampilan berpikir kritis dibandingkan pendekatan parsial, dengan perbedaan skor rata-rata sebesar 22,62. Dengan demikian dapat diurutkan pendekatan yang lebih efektif adalah pendekatan terpadu modle nested, kemudian model connected, dan yang terakhir adalah pendekatan parsial; (3) Berdasarkan hasil observasi, kemampuan peserta didik dalam mengembangkan keterampilan berpikir kritis sudah berada dalam kategori mampu mengembangkan keteraampilan berpikir secara kritis. Hal ini dibuktikan dengan tercapainya skor sebesar $83,33 \%$.

\section{Saran}

Saran yang dapat disampaikan adalah: (1) Berdasarkan hasil penelitian terbukti bahwa pendekatan terpadu dapat menjadi salah satu alternatif pendekatan pembelajaran yang dapat melatih peserta didik berpikir kritis. Pendekatan parsial dalam mengajar sejarah perlahan-lahan dapat diminimalisir, digantikan dengan pendekatan terpadu model nested atau connected yang lebih holistik dalam pembelajaran sejarah, untuk mengembangkan pembahasan sejarah yang kritis dan analitis.; (2) Perlunya konsistensi untuk mengembangkan pendekatan atau strategi pembelajaran yang dapat mengembangkan keterampilan berpikir kritis pada peserta didik.

\section{Ucapan Terima Kasih}

Dalam kesempatan ini, penulis mengucapkan terima kasih kepada berbagai pihak yang telah membantu 
terlaksananya penelitian ini. Tak lupa, penulis juga menyampaikan ucapan terima kasih kepada dewan redaksi Jurnal Istoria terbitan Pendidikan Sejarah, Fakultas Ilmu Sosial, Universitas Negeri Yogyakarta atas kesempatan yang diberikan sehingga tulisan ini dapat dipublikasikan pada edisi Maret 2015.

\section{Daftar Pustaka}

Aman. (2011). Model evaluasi pembelajaran sejarah. Yogyakarta: Penerbit Ombak.

Arikunto, Suhaisimi. (2012). Dasar-dasar evaluasi pendidikan . Jakarta: Bumi Aksara.

Ebosele, P.E. (2012). Critical thinking : essence for teaching mathematics and mathematics problem solving skill. African Journal of Mathematics and Computer Science Research. 5. Pp.39-43. Diakses pada tanggal 13 Desember 2013 dari http://www. academicjournals.org

Fisher, A. (2008). Critical thinking: an introduction (terjemahan Benyamin Hadinata). Jakarta: Erlangga.

Fogarty, R. (1991). How to integrated the curricula. Palatine, Ilinois: IRI/ Skylight Publishing, Inc.

Hasyim, Hafidz. (2012). Watak peradaban dalam epistemologi Ibn Khaldun. Yogyakarta: Pustaka Pelajar.

Kementrian Pendidikan dan Kebudayaan. (2013). Buku guru Sejarah Indonesia kelas X. Jakarta.

Murti, Bisma. (2012). Berpikir kritis (critical thinking). Ilmu Kesehatan Universitas Sebelas Maret. Diakses pada tanggal 26 Desember 2012 dari arl.blog.ittl /kom.ac.id/.../

Pusat Kurikulum. (1996). Model pembelajaran terpadu IPS. Badan Penelitian dan Pengembangan Pendidikan Nasional.

Santrock, J.W. (2004). Psikologi pendidikan. Jakarta: Kencana.

Savage, T. V. \& Amstrong, D. G. (1996). Effevtive teaching in elementary social studies. New Jersey : Simon $\&$ Schuster Company.

Schafersman. (1991). An introduction to critical thinking. Diakses pada tanggal 1 Juli 2013 dari http://www.freeinquiryjournal.com/ critical thinking. 